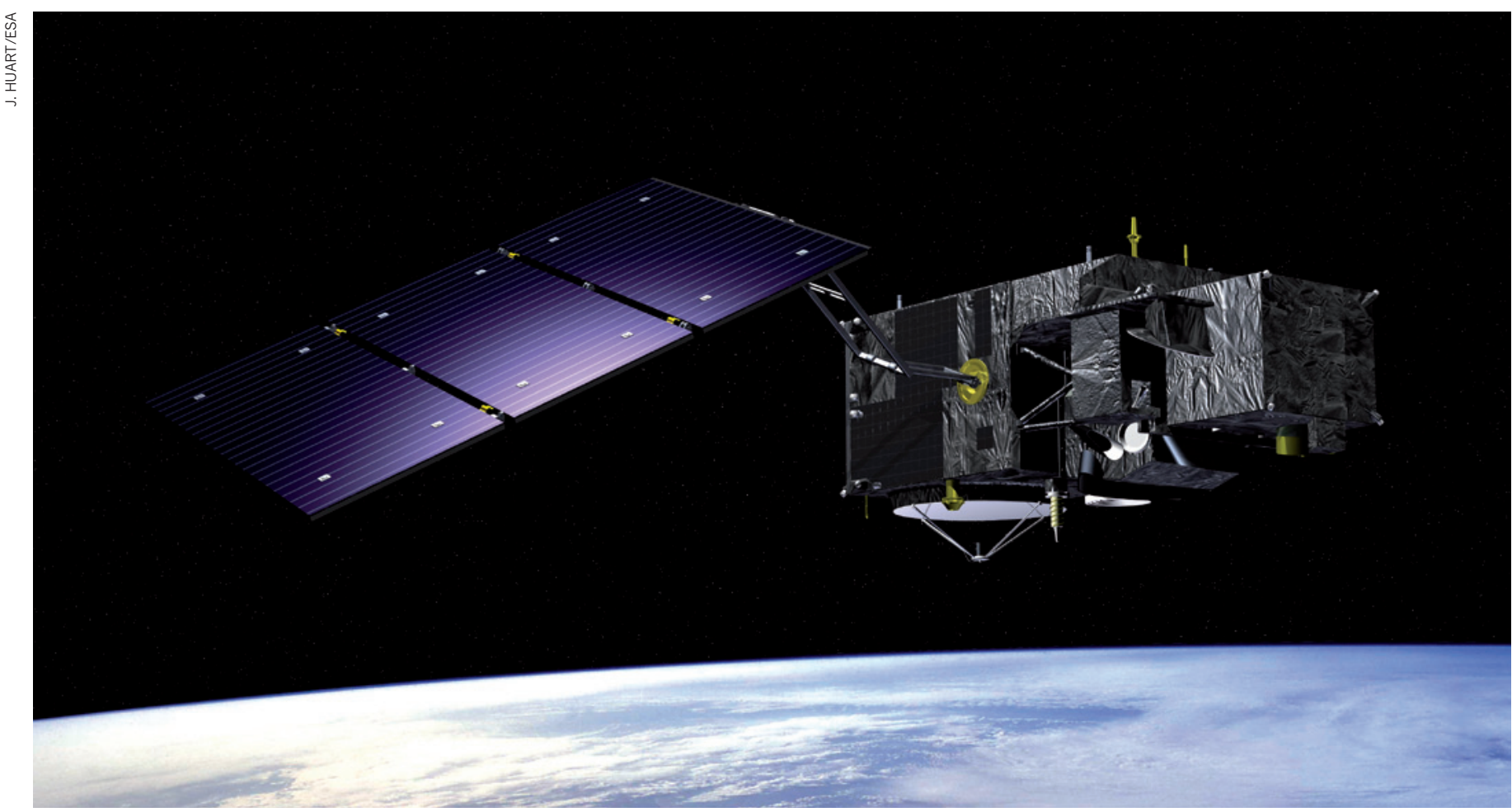

Europe's Earth-monitoring programme GMES is scheduled to begin launching a fleet of satellites in 2013 , but its funding future is now uncertain.

\title{
Outcry over EU budget plan
}

\section{Costly Earth-monitoring and fusion-energy projects could be stripped from main budget.}

\section{BY DECLAN BUTLER}

$\mathrm{A}$ $s$ Europe's financial crisis deepens, a storm is also brewing over proposals that would change how two giant science and technology projects are funded.

Both ITER - the international effort to build a fusion-energy test reactor - and an ambitious Earth-observation project called the Global Monitoring for Environment and Security (GMES) programme are too costly to remain under the general budget of the European Union (EU), according to proposals from the European Commission. The solution, it says, is to corral funding for both projects separately from the next general budget, which will span 2014-20.

The commission suggests that the projects - along with future large-scale science programmes - be supported through new intergovernmental organizations. EU member states would fund these bodies, perhaps along with an additional, capped contribution from the EU budget. This arrangement would reduce the main EU budget's exposure to the large cost overruns that are common in big science projects, the commission argues.

The plan has already sparked vigorous

opposition from several member states and from scientists. On 10 November, ministers from eight member states, including Germany, France and Italy, wrote to Máire GeogheganQuinn, the EU research commissioner, as well as the industry and budget commissioners, warning that the proposal "would only lead to the weakening of these two projects both in terms of funding and governance". The proposal is likely to go through tortured negotiations between the commission, the Council of Ministers and the European Parliament right up until the 2014 budget settlement.

ITER is undoubtedly the highest-profile example of the strain that enormous projects can put on the EU budget. Crisis talks are scheduled for 1 December in Brussels to find a way to make up a $€ 1$.2-billion (US\$1.6billion) hole in funding for ITER's construction. If a solution is not found in the coming weeks, work at the ITER site in Cadarache, France, could face major delays.

\section{DNATURE.COM}

For news of the

Horizon 2020

budget proposal see:

go.nature.com/6uegfo
In 2006, ITER was projected to cost $€ 5$ billion, but that sum has now grown to $€ 15$ billion, forcing the European Commission into a series of financial contortions to make up repeated shortfalls. To insulate the rest of the EU budget from ITER's bloat, the commission is proposing that for 2014-20, Europe's anticipated $€ 2.7$-billion spending on ITER should be channelled through a separate fund.

The commission also wants to make a similar arrangement for GMES, which is expected to cost $€ 5.8$ billion over the same period. The programme, led by the EU with the European Space Agency (ESA) as a major partner, aims to launch a fleet of five families of 'Sentinel' satellites. Drawing on data from other existing or planned satellites and ground sensors, GMES would generate continuous, crosscalibrated, long-term data sets on the state of the planet and its atmosphere. The system would act as a weather service writ large, delivering images, maps, models and forecasts to users 24 hours a day, 365 days a year. Its capabilities would include monitoring and forecasting of climatic change, flood risks, soil and coastal erosion, crop and fish resources, air pollution, greenhouse gases, iceberg distribution and snow cover.

The commission is expected to release detailed proposals for GMES funding this week. But Nature has already learnt that the 
plan would require the $27 \mathrm{EU}$ member states to pay into a GMES fund, with contributions calculated pro rata according to each state's gross national income. Parallel proposals for a change to ITER's funding mechanism are expected on 13 December.

\section{ON THE CUSP OF REALITY}

The timing of the commission's proposals could hardly be worse for GMES, whose organizers plan to start launching its satellite fleet in 2013. "Europe, for once, has taken [world] leadership to develop a very comprehensive Earth-observation system, with multiple satellites and instruments at the technological cutting edge," says Josef Aschbacher, the head of GMES at ESA, based in Frascati, Italy. "We are now on the cusp of making this a reality."

He notes that the project has an exemplary record of staying on budget, even during its long and financially risky research and development phase. Once the satellites enter into operation in 2014, costs will become much more predictable and easier to control. But "we cannot launch the satellites if we have no guarantee that the operational funding and governance structure will be in place afterwards", Aschbacher says.

A new funding mechanism would require unanimous agreement among the EU member states and could take at least five years to

establish, he adds, posing a serious setback for the project or killing it altogether.

Aschbacher says that he is now "very concerned" for GMES's future, and notes that a working document accompanying the commission's budget proposals seemed to contradict the proposals, concluding that taking GMES out of the main EU budget entirely

\section{"Europe, for} once, has taken world leadership to develop a very comprehensive

Earthobservation system." before the programme was firmly established would "create high uncertainty for GMES" and "more than likely... mean a discontinuation of GMES".

Some observers speculate that the commission is using this potential threat to GMES as a bargaining chip to win concessions from member states on other issues, and that, ultimately, a compromise solution to its funding will be hammered out.

\section{CREATIVE ACCOUNTING}

Meanwhile, ITER's financial problems are much more pressing. As part of general budget negotiations in November, ITER was thrown an extra $€ 100$ million for next year, but efforts to find the remaining $€ 1.2$ billion to cover cost overruns have failed.
On 23 November, a 'trilogue' of the council, commission and parliament could not agree on a commission proposal to scrape the money together from other parts of the EU budget. It suggested transferring $€ 300$ million from the Framework research budget; $€ 600$ million from the agriculture budget; $€ 240$ million from the EU administration budget; and $€ 25$ million from the justice, home affairs and education budget.

The result was a stalemate, so another trilogue will be held on 1 December. One source close to the negotiations says he is "cautiously optimistic" that a solution will be found at this meeting. If not, says Michel Claessens, a spokesman for ITER, there will be "significant delays" to the construction of "nearly all the buildings of the ITER site".

\section{CLARIFICATION}

The News story 'Summit urged to clean up farming' (Nature 479, 279; 2011) relied on a draft report supplied by the Commission on Sustainable Agriculture and Climate Change that stated that agriculture is the "single largest contributor to greenhousegas pollution". The final version of the report states that agriculture is "a significant contributor to greenhouse gas emissions". 